\title{
Investigating the Impact of Weekly Weblog Assignments on the Learning Environment of a Secondary Biology Course
}

\author{
Eric Brunsell and Christopher Cimino
}

University of Wisconsin

\begin{abstract}
A weblog, or blog, presents an intriguing way to create a collaborative space within a traditional classroom structure. Well-constructed blog assignments may provide a safe environment and encourage a collaborative learning culture. This study explores the use of blog-based assignments on student participation in a high school biology course. Data collected from field notes, surveys, student interviews, and quiz scores provided evidence that the blog assignments had a positive impact on in-class participation rate, self-directed research, achievement, and classroom environment.
\end{abstract}

Keywords: weblog; blog; blog-based assignments 


\section{Investigating the Impact of Weekly Weblog Assignments on the Learning Environment of a Secondary Biology Course}

Donovan and Bransford (2005) identified four interconnected lenses-learner-centred, knowledge-centred, assessment-centred, and community-centred-through which we can examine effective teaching. The community-centred lens focuses on building inter-personal relationships in the classroom that encourage the sharing of ideas, questioning, risk-taking, and respect. One primary way of building this type of classroom culture is through fostering dialogue. Unfortunately, much of the dialogue that takes place in the science classroom may not be productive in supporting the social construction of knowledge (Newton, Driver \& Osborne, 1999).

The purpose of this study was to explore the impact of a classroom weblog (blog) on the learning environment of a secondary biology course. The study was conducted in a large school district in California. The population of the school is approximately 1200 students, many of which come from single parent or non-traditional families. Most of the students are from lowermiddle class or low-income families. Approximately one third of the students are in poverty as measured by participation in free and reduced lunch programs. The school is ethnically diverse with high percentages of Hispanic, African-American, Asian, Russian and Ukrainian students.

\section{A Review of Relevant Literature}

Social constructivist theories view knowledge construction as a result of individuals interacting in social environments to create shared knowledge that is appropriated by the individual. The context within which learning occurs involves a fabric of shared meanings and understanding that develops when groups of people come together and engage in joint activity over a period of time (Cole, 1996). The participants are molded by and contribute to this context. Since an individual can participate in many cultures as they associate in different groups (e.g. school, home, geographical, racial, etc.), the interactions between cultures provide a lens that mediates what and how an individual learns.

In a social constructivist approach, students should be provided with opportunities for reflective interaction between students to support the co-construction of knowledge. However, prolonged discussions rarely occur in secondary science classrooms. The dominant form of interaction in the classroom is teacher talk. When opportunities are provided for student talk, through teacher questioning, they invariably lead to students "guessing what is in the teacher's mind," instead of assisting the development of understanding through student contribution of emerging understandings (Newton, Driver, \& Osborne, 1999).

Newton, Driver, and Osborne (1999) explain that the type of discourse usually seen in science classrooms gives the false impression of science as an "unproblematic collection of facts about the world." It fails to empower students with the ability to examine critically scientific claims and knowledge. Students should be engaged in instructional conversations that provide extended dialogue around concepts. Instructional conversations allow students to identify, compare, and refine different lines of thought, are student-directed, and give students a greater voice. During instructional conversations, students converge on themes and build consensus on explanations for phenomena. The change in the way students think happens as others' perspectives restructure, alter, or fine-tune a student's personal knowledge (Mason \& Santi, 1998; Hatano \& Inagaki, 2003; Eryilmaz, 2002; Vosniadou, Ioannides, Dimitrakopoulou, \& 
Papademetriou, 2001). Instructional conversations also foster an environment that promotes learning for understanding over learning for obtaining a good grade (Pintrich \& Sinatra, 2003).

Blogs provide both teachers and learners with the ability to extend discussions beyond the traditional face-to-face classroom. Blogs are an ideal forum for the social construction of knowledge because they can provide opportunities to share ideas and experiences and negotiate understandings with others (Ferdig \& Trammell, 2004; Ahern et al., 2006). Members of a classroom blog tend to get more involved then they do in other environments (Efimova \& Fiedler, 2003; Godwin-Jones, 2008). Blogs foster a feeling of community among participating students as they co-create knowledge through posts and comments. Students using a classroom blog often feel a responsibility to contribute in order to help the entire class succeed. This feeling of responsibility is a result of shared ownership and encourages pro-social behaviors (Calvert, 1999; Dickey, 2004; Liaw, Chen \& Huang, 2008).

A well-constructed classroom blog creates a learner-centered environment that allows students to take a more active role in their learning. Students can publish their own writing, whether it's a journal, a story, or comments on class readings (Kennedy, 2003). Students can archive and analyze writings, and conduct peer critiques (Mortenson \& Walker, 2002; MacBride \& Leuhmann, 2008). Teachers can also use a blog to build a rich learning resource by linking to online testing sites to provide opportunities to practice and monitor learning, exposing students to concepts using multiple media formats, and by providing hyperlinks to additional resources that allow for student self-directed exploration within the topic (Efimova \& Fiedler, 2003). All of these activities can lead to robust interaction between students.

\section{The Biology Blog}

This study was conducted in one "average performing” 10th grade Biology class consisting of 36 students. The demographics of the class were representative of the school, including ten Hispanic students, two African-American students, three Asian students, and two Ukrainian students. Biology courses met every day for 8 weeks in a 90-minute block schedule.

Blog assignments were posted every Friday and were due the following Thursday for the duration of the course. These assignments provided opportunities for discussion, online activities and concept review. The discussions were generally tied to an online activity related to the concepts being covered that week. Each student was required to post at least once to the initial discussion topic and two additional comments on their classmates' posts. The instructor served as a moderator providing guidance and focus only when needed. The vast majority of discussion was between students. Figure 1 shows an example of a weekly blog assignment that includes online readings. Figure 2 provides an example of a weekly Biology Blog assignment that requires the completion of an online lab component.

Electronic Assignment

Read the online article Genetic Engineering - Fast Forwarding to Future Foods by the Food and Drug Administration and the Cloning Fact Sheet from the Human Genome Project.

Write a short summary for each in Word format. Follow the format for article summaries listed in your class syllabus. Email your completed summaries as an attachment to Mr. C by 10:00 PM Thursday. 


\section{Discussion Component}

Science has made great strides in the area of genetic technology however; genetic engineering tends to be one of the most hotly debated subjects among scientists and nonscientists alike. Post your thoughts regarding genetically altered foods and cloning of animals. Consider any possible benefit or risk that may be involved. It is strongly advised that you read the articles listed in the Electronic Assignment prior to posting.

Here are some questions you may want to consider...

What if the world's hunger problem could be solved? Is it worth the risk in your opinion? Should cloning of mammals be allowed?

What about humans? Are there benefits to cloning humans?

Remember to post well thought out, intelligent responses and use appropriate scientific terminology when possible. You must make an initial post and respond to at least one classmate's initial post for credit. It's fine to disagree but do so in a courteous, respectful manner. Remember to always play nice. Initial posts must be made by 9:00 PM Tuesday for credit. All posts must be made by 10:00 PM Thursday.

\section{Online Quiz}

Complete this week's online quiz (Review) by 10:00 PM Thursday. Scores will be automatically forwarded to Mr. C. Don’t forget to study for Friday's written quiz.

Figure 1. An example Biology Blog assignment for genetic technology that uses out-of-class readings.

\section{Electronic Assignment}

Complete the online mitosis lab assignment entitled Onion Root Tips.

Read the instructions and prelab information. Complete the assignment and turn in your completed data table to Mr. Cimino by the beginning of the period on Thursday.

We will be performing an in class lab using root tip slides on Thursday, as well.

\section{Discussion Component}

Discuss a creative and helpful method for remembering the phases of mitosis. You may come up with one of your own or research the internet for a method YOU WILL USE to help you learn to identify the phase and activities of mitosis. You may not simply state that you will memorize the info in the book or that I'm such a great teacher that you don't need anything to help you remember. You must discuss a technique for learning. It can be serious, crazy, funny, etc. as long as it helps you remember the phases. Here are some hints to get you started...

Ever use a mnemonic? 
YouTube has more than just skateboard videos.

How about a catchy jingle?

Post your method and comment on another student's initial post for credit.

Online Quiz

Complete this week's online quiz by 10:00 PM Thursday. Scores will be automatically

forwarded to Mr. Cimino. Don’t forget to study for Friday’s written quiz.

Figure 2. Biology Blog assignments for mitosis and cell division.

\section{Evaluating the Biology Blog Experience}

The purpose of this study was to explore the impact of using weekly blog assignments on the learning environment in a secondary biology course. We used a pragmatic, utilization-focused evaluation framework (Patton, 1997). The goal of this framework is to generate practical and useful knowledge for action. The results of our study can potentially add to the knowledge base of how to use blogs to develop a sense of a community of practice within a classroom. We expect that professional development facilitators and classroom teachers may find the results useful as prompts for pedagogical discussions and as a model for action. In a utilization-focused evaluation framework, it is important to identify explicit outcomes that are useful to the intended audience. Therefore, we selected four practical focus questions.

- Will using a Biology Blog increase student participation?

- Will using a Biology Blog promote self guided study and research?

- Will the use of a Biology Blog increase student quiz scores?

- Will the use of a Biology Blog create a comfortable learning environment for students?

To enhance the credibility of evaluative research, evidence from two or more sources should be used to converge or triangulate on the same set of findings. Evidence can be collected from different individuals, types of data, or mixed methods of data collection (Creswell, 2005). Table 1 summarizes the data collection methods used in this study.

Data was collected by monitoring completion of blog assignments, student surveys and interviews, weekly quiz scores, and field notes. One "perceptions" survey was given at the beginning of the study and during the 5th week. A second survey was given at the end of the study to determine students' reactions to different aspects of the Biology Blog assignments. Five males and five females were also selected randomly for the post-study interviews. With one exception, data was only collected from the class of students participating in the blog assignments. Class participation data was also collected with a teacher journal in two similar biology classes that were not using the blog assignments.

Data was analyzed on a question-by-question basis. The analysis process began by reviewing interview data. Transcripts were organized into segments based on the focus questions. Each segment was read multiple times to generate categories and to identify patterns. After this process was completed, we compared the interview trends to data collected through surveys, classroom tasks (blog completion rates, online and in-class quizzes), surveys, and the 
teacher journal. A series of claims for each focus question emerged from the data and each was supported by multiple sources of evidence.

\section{Table 1}

A Summary of Data Collection Methods

\begin{tabular}{|l|l|l|l|}
\hline \multicolumn{1}{|c|}{ Research Questions } & Data Source \#1 & Data Source \#2 & $\begin{array}{c}\text { Data Source } \\
\text { \#3 }\end{array}$ \\
\hline $\begin{array}{l}\text { Will the use of a weekly } \\
\text { Biology Blog increase student } \\
\text { participation? }\end{array}$ & $\begin{array}{l}\text { Completion of blog } \\
\text { discussion, electronic } \\
\text { assignment, and online } \\
\text { quiz. }\end{array}$ & $\begin{array}{l}\text { Student } \\
\text { surveys and } \\
\text { teacher journal. }\end{array}$ & $\begin{array}{l}\text { Student } \\
\text { interviews. }\end{array}$ \\
\hline $\begin{array}{l}\text { Will the use of a weekly } \\
\text { Biology Blog result in self- } \\
\text { directed research? }\end{array}$ & $\begin{array}{l}\text { Completion of blog } \\
\text { discussion and } \\
\text { electronic assignment. }\end{array}$ & $\begin{array}{l}\text { Surveys. } \\
\text { Student }\end{array}$ & $\begin{array}{l}\text { Student } \\
\text { interviews. }\end{array}$ \\
\hline $\begin{array}{l}\text { Will the use of a Biology } \\
\text { slog increase student quiz } \\
\text { scores? }\end{array}$ & $\begin{array}{l}\text { Individual scores and } \\
\text { class average on } \\
\text { assigned quizzes. }\end{array}$ & $\begin{array}{l}\text { Student } \\
\text { surveys. }\end{array}$ & $\begin{array}{l}\text { Student } \\
\text { interviews. }\end{array}$ \\
\hline $\begin{array}{l}\text { Will the use of a Biology } \\
\text { learning environment for } \\
\text { students? }\end{array}$ & Student surveys. & $\begin{array}{l}\text { Student } \\
\text { interviews. }\end{array}$ & \\
\hline
\end{tabular}

\section{Baseline Survey}

We surveyed the students prior to beginning the weekly blog assignments to determine their initial perceptions of using a class blog. Surprisingly, most students (44\%) had a negative perception of the upcoming blog. One-third of the students had a positive perception and the remaining students were either indifferent or unsure. Many of the negative responses can be attributed to students' belief that the blog would add to their workload as expressed by this typical response, "I don't think the computer blog assignment is necessary because we already have enough work to do in this class." Another student replied, "Doing my work on a computer isn't going to make it any better, it's just going to be more work." Approximately $30 \%$ of the negative and indifferent comments discussed the lack of access to technology in the home. One student replied, "I don't have a computer at home. How am I going to do the assignment if I can't get it done in class?” Another replied, “We don't have the Internet at home. It's not fair to make us do an assignment that uses the Internet." Some of the positive replies included, "Using the computer for a lab or quiz will be kind of cool. I like the idea of doing labs and quizzes at home.” Another student replied, "Participating in an online discussion will put less pressure on 
me if I can do it over the Internet. I like the idea of being able to think about what I want to say before I answer.”

After reviewing this initial survey, we reassured students of the process. The blog assignment would not considerably affect the workload in class and students would have access to the blog assignment via seven lab station computers located in the classroom. Students would be allowed to log in before school, after school, and during school, when they have free time.

\section{Will Using a Biology Blog Increase Student Participation?}

Data sources for this focus question include completion records for blog assignments, student surveys and student interviews. Students maintained a high level of participation in the Biology Blog discussions throughout the duration of the study. On average, $93.4 \%$ of students completed the discussions each week. This average is even higher if you discount the lower participation during Week 4, which may have been caused by a higher level of absences. Figure 3 shows weekly completion rates. This high level of completion shows that access to computers and the Internet was not an issue.

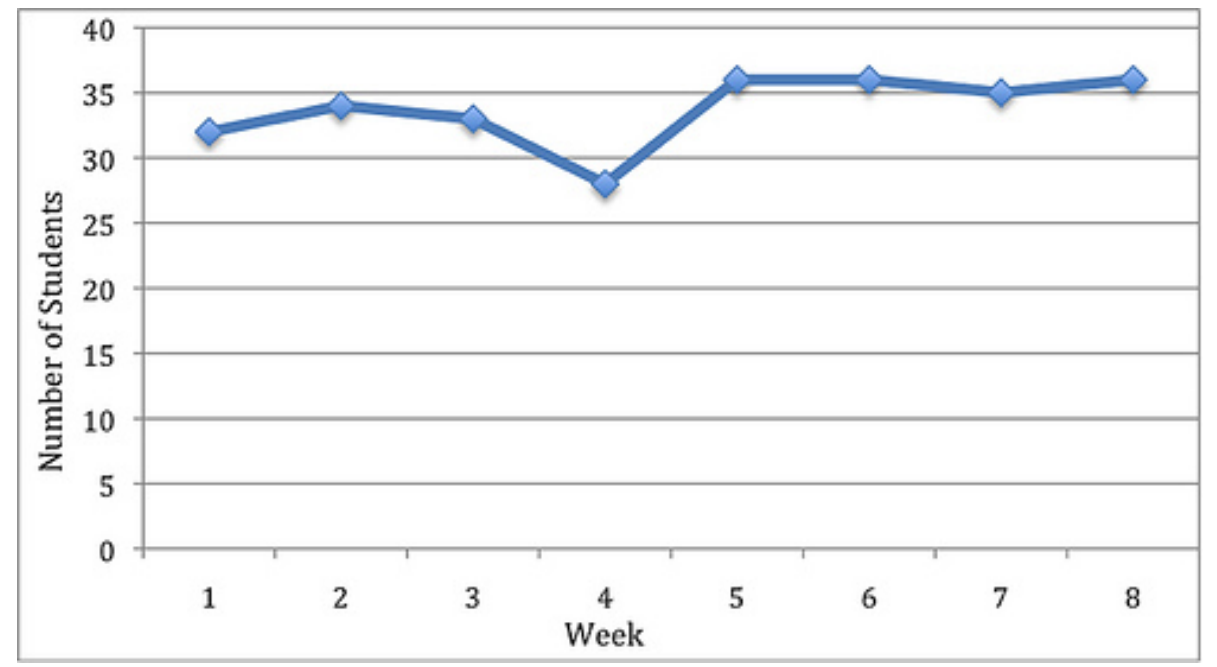

Figure 3. Online student participation ( $\mathrm{N}=36)$.

Feelings towards the online component of the Biology Blog were overwhelmingly positive. Student attitudes revealed in a post-intervention student survey revealed that most students felt comfortable participating in the online blog assignments. In fact, over $94 \%$ of the students expressed that they felt a higher comfort level participating in the online discussion and assignments when compared to the in-class discussions. Table 2 summarizes the responses for this portion of the post-intervention survey.

\section{Table 2}

Student Survey Regarding Online Participation in the Biology Blog $(N=36)$

\begin{tabular}{|l|l|l|l|}
\hline Survey Question & Agree & Neutral & Disagree \\
\hline I felt comfortable completing the online assignments. & 34 & 0 & 2 \\
\hline
\end{tabular}




\begin{tabular}{|l|l|l|l|}
\hline Survey Question & Agree & Neutral & Disagree \\
\hline $\begin{array}{l}\text { I felt more comfortable participating in online } \\
\text { discussions than in-class discussions. }\end{array}$ & 34 & 1 & 1 \\
\hline $\begin{array}{l}\text { The online assignments and discussion helped me } \\
\text { perform better on written assignments. }\end{array}$ & 30 & 4 & 2 \\
\hline \begin{tabular}{l} 
I hope to have a similar blog available in other courses. \\
\hline
\end{tabular} & 32 & 2 & 2 \\
\hline
\end{tabular}

Student comments during the post-intervention interview supported the survey findings of an overall positive reaction towards the Biology Blog. When asked how they felt about the online discussions and assignments as opposed to in-class discussion one student commented, "I didn't feel pressured when participating in the online blog discussion. I was able to think about my answers and look them up before posting. You can't really do that in class." Another student went on to mention, "I didn't have to worry too much about being wrong before saying something." Another student replied, "I liked being able to type rather than talk. It was a little like texting which is what I do a lot." One student who was interviewed liked the blog assignments but didn't feel they had contributed to his success. "I would have done just as well without the blog. It didn't really help me become a better student.” We followed up by asking him if he felt it could have made a fellow classmate a better student. He replied, "I never really thought of that. Yes, I guess I could have unknowingly helped others in the class by posting my answers and offering suggestions." The student went on to say, "It was probably really helpful to them... kind of like online tutoring in a way. Can I get extra credit for that?”

Field observations were used to measure student participation during in-class (face-toface) discussions. Student participation increased from just fewer than $17 \%$ in Week 1 to just over $72 \%$ in Week 8 . Participation during Week 4 was negatively impacted by a higher than normal rate of absences. The voluntary participation rates for each week are displayed in Figure 4. The participation for the class using the Biology Blog was much higher than the 15-25\% participation found in the instructor's other Biology classes. 


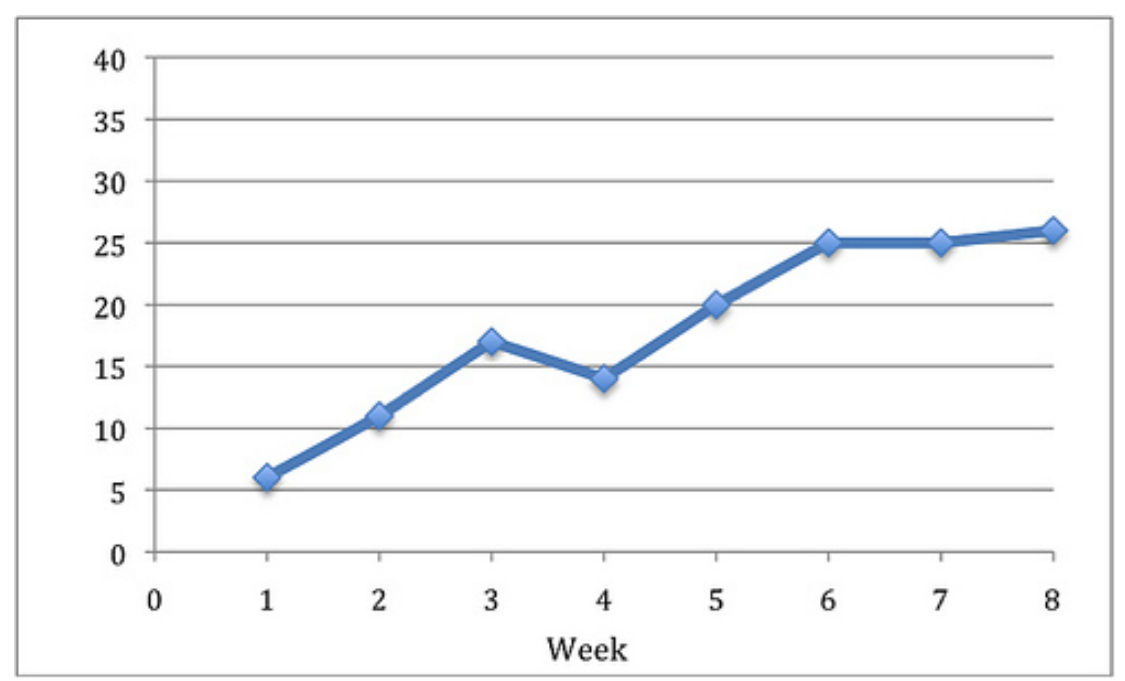

Figure 4. In-class student participation ( $\mathrm{N}=36)$.

Considering the rate of in class participation increased steadily throughout the study, it can be surmised that the use of the Biology Blog gave students a greater feeling of comfort when it came to participating within the classroom. This was especially evident from the fact that inclass participation increased throughout the course of the study. Student surveys and interviews revealed that several students felt an increase in confidence towards the subject matter and were less hesitant when it came to offering an answer or explanation during class. One student who began to participate in class during Week 5 of the study responded, "In the beginning of the class I was afraid to raise my hand and look stupid. The blog assignments made me feel more confident each week so I was no longer afraid to look stupid.” Another student replied, “After getting used to talking to everyone on the blog it didn't seem like such a big deal to give an answer in class." The comment also suggests that the students were becoming a community of learners rather than 36 individuals.

Approximately 10 students did not voluntarily participate in the classroom discussions or question/answer segments; however, eight of these students would participate if called upon by the instructor. There were two students in particular that would not readily participate in class on a regular basis.

The postintervention survey also included questions to determine students' perceptions of the impact of the Biology Blog on class participation. According to the survey, $41.7 \%$ of the students felt that they were uncomfortable in regards to class participation prior to use of the Biology Blog. Use of the blog was cited by $72.2 \%$ of the students as having helped give a feeling of confidence towards class participation. More than $80 \%$ felt that the blog helped them become better prepared to participate and were glad that the Biology Blog assignments were used during the semester. Prior to implementing the blog nearly $80 \%$ of students felt a lack of confidence when volunteering answers or opinions in class. This decreased to $11 \%$ by the end of the study. Results from this portion of the survey are summarized in Table 3.

\section{Table 3}

Student Survey Regarding In-Class Participation as it Relates to the Biology Blog $(N=36)$ 


\begin{tabular}{|l|l|l|l|}
\hline Survey Question & Agree & Neutral & Disagree \\
\hline $\begin{array}{l}\text { Before the blog, I felt comfortable raising my hand to } \\
\text { participate in class. }\end{array}$ & 8 & 5 & 23 \\
\hline $\begin{array}{l}\text { The blog helped me feel confident when giving an answer } \\
\text { or comment in class. }\end{array}$ & 26 & 2 & 8 \\
\hline $\begin{array}{l}\text { The blog helped me be better prepared for the material } \\
\text { presented in class. }\end{array}$ & 30 & 1 & 5 \\
\hline \begin{tabular}{l} 
I am glad we use a Biology Blog this semester. \\
\hline
\end{tabular}
\end{tabular}

\section{Will the Use of a Weekly Biology Blog Result in an Increase in Self-Directed Research?}

As with the online and in-class participation components the class had a very high percentage of students that performed self-directed research in response to the Biology Blog assignments. Self-directed research was defined as seeking out information in text or video forms from a source other than the class textbook. Acceptable forms of research included the Internet, encyclopedia, journal articles, and educational videos. At the end of each week, all participating students were given a questionnaire asking if they performed self-directed research in relation to the online Biology Blog requirements. During the first 3 weeks of the study few students completed self-directed research. However, by Week 4 each participating student began performing self-directed research in order to complete or enhance performance. Students continued to perform self-directed research for the remaining weeks.

A student survey taken at the end of the study gave overwhelming evidence that nearly all participating students felt it was necessary to perform research in order to complete the task. Many indicated that they most likely would not have performed any self-directed research had it not been for the blog assignment. Almost all (94\%) of the students stated that the self-directed research helped them learn the subject matter and $86 \%$ of the students indicated that they would continue this practice in future courses. Student interviews were very positive. The following student response was typical of the group interviewed, "I probably would have never thought to look up information on the computer just to complete an assignment or get in a discussion had it not been for the blog." This answer is surprising considering the availability of Internet access. When asked why this was the preferred method of research one student replied, "It's easy to just Google the information while on the computer and there is a ton of information out there. It's a lot easier than getting out the encyclopedia." Another student commented, "You had us do the assignment on the computer so it seemed normal to look up the answers on the computer." Nearly all the participating students used the Internet as their preferred method of research.

\section{Will the Use of a Biology Blog Increase Student Quiz Scores?}

Students participating in the study were required to complete an online review quiz and a written quiz each week. The online quiz was to be completed by 10:00 p.m. on Thursday and the written quiz was administered each Friday in class. Quiz scores from both written and online 
sources were counted towards the student's overall class grade. In-class quizzes were closed book/closed notes, multiple-choice style quizzes. Each written quiz consisted of 20 questions. The online quizzes consisted of 15 questions with each question containing a "Hint" link in case a student needed assistance. It was never stated in class whether the online quiz was open or closed book/notes due to the impossibility of enforcement of a closed book quiz. The purpose of the online quiz was to help students monitor their learning, not to give them answers to the inclass quiz. Therefore, the in-class and online quizzes covered similar concepts, but used different questions.

Individual scores were collected as data for this portion of the study. Scores earned on the online quizzes remained above average throughout the study without much fluctuation. Written quiz scores increased throughout the research period. The online quiz scores were approximately $10 \%$ greater than the traditional scores throughout the study. This was to be expected considering the online quizzes had a link to special hints and was essentially an open book/note style quiz with no time limit other than the due date. What is important to note is that both sets of scores increased over the period of the study. The initial mean score percentage for the online quizzes was $88.7 \%$ and increased to $98.0 \%$ by Week 7 , dropping very slightly in Week 8 to $97.3 \%$. The traditional quiz scores increased each week, ranging from $80.4 \%$ in Week 1 to $87.4 \%$ in Week 8. Table 4 summarizes weekly online and written quiz scores. In order to determine if the increase in quiz scores was significantly, we compared scores for Weeks 1 and 5 and Weeks 5 and 8. Weeks 1 and 5 were significantly different, $\mathrm{t}(70)=6.96, \mathrm{p}<0.0001$. Weeks 5 and 8 were significantly different, $\mathrm{t}(70)=5.08, \mathrm{p}<0.0001$, with Week 8 being the higher score.

\section{Table 4}

Weekly Written Scores During the Biology Blog Intervention

\begin{tabular}{|l|l|l|l|l|}
\hline Week & Online & Standard Deviation & Written & Standard Deviation \\
\hline 1 & $88.7 \%$ & 1.54 & $80.4 \%$ & 2.39 \\
\hline 2 & $90.0 \%$ & 2.03 & $81.0 \%$ & 2.9 \\
\hline 3 & $92.7 \%$ & 1.83 & $82.8 \%$ & 2.52 \\
\hline 4 & $92.0 \%$ & 1.67 & $83.3 \%$ & 2.1 \\
\hline 5 & $95.3 \%$ & 1.05 & $84.2 \%$ & 2.24 \\
\hline 6 & $94.7 \%$ & 1.48 & $85.4 \%$ & 2.29 \\
\hline 7 & $98.0 \%$ & 0.91 & $86.1 \%$ & 2.06 \\
\hline
\end{tabular}




\begin{tabular}{|l|l|l|l|l|}
\hline Week & Online & Standard Deviation & Written & Standard Deviation \\
\hline 8 & $97.0 \%$ & 0.8 & $87.4 \%$ & 3.04 \\
\hline
\end{tabular}

The student survey given at the end of the study revealed that most students felt that the online review quiz helped increase success and preparedness for the written quiz. The positive responses on the student survey indicated all students were comfortable with the online quiz and nearly all students felt they benefited by taking the online quiz. The student survey is listed in Table 5.

\section{Table 5}

Student Survey Regarding Online Quiz Component

\begin{tabular}{|l|l|l|l|}
\hline Survey Question & Agree & Neutral & Disagree \\
\hline I felt comfortable taking the online quiz. & 35 & 0 & 1 \\
\hline $\begin{array}{l}\text { The online quiz made me better prepared to take the } \\
\text { written quiz. }\end{array}$ & 32 & 2 & 2 \\
\hline $\begin{array}{l}\text { I believe the online quiz helped increase my written } \\
\text { scores. }\end{array}$ & 33 & 3 & 2 \\
\hline I believe that the online quiz made me a better student. & 32 & 2 & 2 \\
\hline
\end{tabular}

The student interviews supported data from the quiz scores and student survey. When asked how the online quiz may have helped with the written quiz a student replied, "All the material from the online quiz showed up on the written quiz in some form or another. It was as if I was getting the answers in advance... sort of" Another replied, "I used the online quiz as a study guide for the real (written) quiz. I took the quiz early, looked up the answers, and then studied them for the Friday quiz." When asked about how the quiz may have helped with their comfort level a student responded, “I didn’t feel pressure taking the online quiz because I always knew I could look at the hint. After a while, I looked at every hint because the hints were helping me with the regular quiz, too.” Not every student agreed that the quiz made him or her better student. One of the highest performing students in the class was asked if the quiz made them a better student. She replied, “No, I'm a pretty good student and I didn't really need the online quiz but it did make it easier to study." A student that has an excellent work ethic but earns no more than a B grade on most assignments stated, "Yes, I'm not a very good test taker but quiz on the computer helped me get three A’s on quizzes during this semester.”

\section{Will the Use of a Biology Blog Create a Comfortable Learning Environment for Students?}

Supporting data for this question were restricted to student surveys and student interviews given at the end of the study period. As much of the data listed in previous sections indicate, the 
class comfort level increased as the study progressed. The data shows that the majority of students considered the Biology Blog to be a positive experience. According to the survey 83\% of the students felt that the requirements of the Biology Blog were reasonable and worthwhile, 94\% felt that they were supported by their peers through the blog, 97\% believed that their views and opinions were valued within the class, and over $80 \%$ of the students felt that the blog increased their overall comfort level within the class. It is worthwhile to note that less than $10 \%$ of the student population felt that the blog did not increase their comfort level with the class. The results of the survey questions are listed in Table 6.

\section{Table 6}

Student Survey Regarding Comfort Level and Value $(N=36)$

\begin{tabular}{|l|l|l|l|}
\hline Survey Question & Agree & Neutral & Disagree \\
\hline $\begin{array}{l}\text { The Biology Blog assignments were reasonable and } \\
\text { worthwhile. }\end{array}$ & 30 & 4 & 2 \\
\hline $\begin{array}{l}\text { My fellow classmates supported my online questions. } \\
\text { My fellow classmates valued my opinions and } \\
\text { contributions to the discussions. }\end{array}$ & 35 & 1 & 1 \\
\hline $\begin{array}{l}\text { The Biology Blog helped me become more comfortable } \\
\text { with this class as time went on. }\end{array}$ & 29 & 5 & 0 \\
\hline
\end{tabular}

Student interviews regarding the comfort level and value of the blog were largely positive and reflective of the student survey data. One student replied, "I always knew I could post a question and someone would answer it." Another replied, "It was kind of like an online study group because there was someone to answer your questions if you got stuck. " Another replied, "I knew Mr. C would answer me if no one else would." Students were also asked what they liked about the Biology Blog. We were surprised to hear that several of the students liked the fact that the instructor was monitoring the discussion on a daily basis. One particular student commented, "I knew you were always on the blog discussion because you have no life!" the student said in jest. "Seriously, I liked knowing Mr. C would log in every night in case I had a question or something." A student expanded further by stating, "Yeah, once I forgot to make my 2nd post and Mr. C sent me an email to remind me." Another interviewee stated, "I liked the way we had about a week to finish the work and I could do it when I had time.” Finally, students were asked if they felt that the class had become a community of learners due to the Biology Blog. Most students agreed that they had. When asked, a student replied, "If you meant that we helped each other with the class then yes." Another explained, "Yes, I think we worked like a team to get through the class. Science can be hard but we all pulled together to get through it.” A slightly less dramatic response was, "Everyone was willing to help each other when needed, even <student name>. I liked that about this class." No negative responses were recorded in the student interviews but there were a few indifferent responses. One response was indicative of the 
indifferent students, “No, I don't think we really tried to work as a team but the blog forced us to discuss and answer each other's questions for credit." However, this student did grow more comfortable with the blog, "Yes, I felt better about it as time went on. At first, I didn't like the blog or the class but as soon as I got the hang of it I felt better about the class."

\section{Conclusion}

At the beginning of this project, we were surprised to find out that the students were apprehensive about having a classroom blog, with many of the students worried that it would increase their workload. Perhaps we naively assumed that the simple introduction of technology would be a motivator by itself. In hindsight, it should be no surprise that using the Internet is not necessarily the "shiny object" that it was a decade ago. However, this study shows that effective use of technology, specifically in ways that allow students to collaborate, can be engaging, motivating and fruitful. In fact, we gave the same "baseline" survey at the midpoint of the project and had very different results. In the initial survey, only 33\% of students had a positive outlook on classroom blogging. By the 5th week of completing blog assignments, all but one student (97\%) had positive perceptions of the project and one was indifferent. Student comments on this survey showed that they were engaged. One particular student commented, "I've done my best to do the blog every week and when I do, I realize that I can understand the material much better." Another stated, "During class when Mr. C is talking about the subject of the blog, I can get into the discussion because I know what we are talking about. Another student replied, "Weekly blog assignments prepare me for the questions in the quiz but mainly it gives me information. I would never research on something about science unless it's for the blog. So when I research I have fun because while I'm answering the blog and I also learn new things.” The sole indifferent response gave a mixed message, “The weekly blog hasn't really helped me as much but overall it has given me a good insight on the test.”

The use of the Biology Blog was an extremely successful and worthwhile endeavor for this class. Initially, most students did not welcome the implementation of the blog requirement perceiving it as just an additional load to bear in an already challenging course. As students became more accustomed to the use of the Biology Blog they gained a sense of confidence through added support from peers and the instructor. They came to appreciate the extra help from less threatening sources, such as their classmates while knowing that the instructor was constantly monitoring to keep the group on course. This increased comfort level spilled over into the classroom resulting in increased classroom participation. Student surveys and student interviews provided evidence that the students felt appreciated and supported both inside the classroom and in the online class community.

This increased comfort and confidence level among students translated into higher quiz scores and increased grades. The Biology Blog stimulated self-directed research among the students. A majority of students claimed that they were compelled to conduct simple online research in order to familiarize themselves in the subject matter prior to, and during the online discussions. This self-directed research helped increase participation, as well as success on scored assignments.

Through the blog discussion, quiz, and assignment requirements students became more knowledgeable and confident in their studies. This confidence resulted in a cycle of learning success. Increased confidence gained through the blog assignments promoted self-guided 
research, which in turn resulted in increased participation within a community of learners and increased learning success among the students. 


\section{References}

Ahern, T.C., Thomas, J.A., Tallent-Runnels, M.K., Lan, W.Y., Cooper, S., Lu, X., \& Cyrus, J. (2006). The effect of social grounding on collaboration in a computer-mediated small group discussion. Internet and Higher Education, 9, 37-46.

Calvert, S. L. (1999). Children's journeys through the information age. Boston, MA: McGrawHill College.

Cole, M. (1996). Cultural psychology: A once and future discipline. Cambridge, MA: Harvard University Press.

Creswell, J. W. (2005). Educational research: Planning, conducting, and evaluating quantitative and qualitative research (2nd ed.). Upper Saddle River, NJ: Merrill Prentice Hall.

Dickey, M.D. (2004). The impact of web-logs (blogs) on student perceptions of isolation and alienation in a web-based distance learning environment. Open Learning, 19(3), 279-291.

Donovan, M.S., \& Bransford, J.D. (2005) How students learn: History, mathematics, and science in the classroom. Washington DC: The National Academies Press.

Efimova, L., \& Fiedler, S. (2003). Learning webs: Learning in weblog networks, In P. Kommers, P. Isaias, \& M.B. Nunes (Eds.), Proceedings of the IADIS International Conference Web Based Communities 2004 (pp. 490-494). Lisbon: IADIS Press.

Eryilmaz, A. (2002). Effects of conceptual assignments and conceptual change discussions on students' misconceptions and achievement regarding force and motion. Journal of Research in Science Teaching, 39(10), 1001-1015.

Ferdig, R.E., \& Trammell, K.D. (2004). Content delivery in the 'Blogosphere.' T.H.E. Journal, Retrieved November 23, 2009, from http://www.thejournal.com/articles/16626

Godwin-Jones, B. (2008). Emerging technologies: Web-writing 2.0: Enabling, documenting, and assessing writing online. Language Learning and Technology, 12(2), 7-13.

Hatano, G., \& Inagaki, K. (2003). When is conceptual change intended? A cognitivesociocultural view. In G. M. Sinatra \& P. R. Pintrich (Eds.), Intentional conceptual change. Mahwah, NJ: Lawrence Erlbaum Associates, Inc.

Kennedy, K. (2003). Writing with web logs. Technology and Learning Magazine, 23. Retrieved October 15, 2008, from http://www.techlearning.com/db_area/archives/TL/2003/02/blogs.html

Liaw, S. S., Chen, G.D., \& Huang, H.M. (2008). Users’ attitudes toward Web-based collaborative learning systems for knowledge management. Computers and Education, 50(3), 950-961.

MacBride, R., \& Leuhmann, A.L. (2008, May). Capitalizing on emerging technologies: a case study of classroom blogging. School Science and Mathematics, 108(5), 173-183.

Mason, L., \& Santi, M. (1998). Discussing the greenhouse effect: Children's collaborative discourse reasoning and conceptual change. Environmental Education Research, 4(1), 6785. 
Mortensen, T., \& Walker, J. (2002). Blogging thoughts: Personal publication as an online research tool. Proceedings of SKIKT-Researchers' Conference 2002 - Researching ICTs in Context, University of Oslo.

Newton, P., Driver, R. \& Osborne, J. (1999). The place of argumentation in the pedagogy of school science. International Journal of Science Education, 21(5), 553-576.

Patton, M. Q. (1997). Utilization-focused evaluation: The new century text (3rd ed.). Thousand Oaks, CA: Sage.

Pintrich, P. R., \& Sinatra, G.M. (2003). The role of Intentions in conceptual change learning. In G. M. Sinatra \& P. R. Pintrich (Eds.), Intentional Conceptual Change. Mahwah, NJ: Lawrence Erlbaum Associates, Inc.

Vosniadou, S., Ioannides, C., Dimitrakopoulou, A., \& Papademetriou, E., (2001). Designing learning environments to promote conceptual change in science. Learning and Instruction, 11, 381-419. 